\title{
Quasi-Z-source Inverter with Coupled Inductor
}

\author{
Zhengyu Zhao \\ School of Engineering \\ Newcastle University \\ Newcastle upon and Tyne, United \\ Kingdom \\ z.zhao6@ncl.ac.uk
}

\author{
Mohammed A. Elgendy \\ School of Engineering \\ Newcastle University \\ Newcastle upon and Tyne, United \\ Kingdom \\ mohammed.elgendy@ncl.ac.uk
}

Musbahu Muhammad

School of Engineering

Newcastle University

Newcastle upon and Tyne, United

Kingdom

musbahu.Muhammad@ncl.ac.uk

\author{
Matthew Armstrong \\ School of Engineering \\ Newcastle University \\ Newcastle upon and Tyne, United \\ Kingdom \\ matthew.armstrong@ncl.ac.uk
}

\begin{abstract}
A novel quasi-Z-source inverter with Coupled Inductor technique is proposed in this paper. The boost ability of the proposed topology is enhanced compared to classic $Z$ source/quasi-Z-source topologies. The proposed topology provides a common mode ground with dc source, continuous input current, reduced voltage and current stress on active and passive components. Better energy utilization and suppressed inrush current are achieved by employing coupled inductor cells. Analytical and simulation results are presented to explore the advantages of the proposed design.
\end{abstract}

Keywords-Quasi-Z-source Inverter (qZSI), Boost Ability, Coupled Inductor

\section{INTRODUCTION}

The Z-source inverter (ZSI) has attracted much attention due to its promising advantages compared to the traditional voltage source inverter (VSI). Firstly, single-stage buckboost inversion of Z-source inverter improves system efficiency compared to the classic double-stage inverter. Secondly, the utilization of shoot-through between upper switches and lower switches of inverter bridges avoids the existence of deadtime which causes distortion in the output current waveform. It also performs better in terms of immunity against EMI noise [1]. However, the main drawbacks of ZSI are high inrush input current, high voltage stress across switches and capacitors and relatively weak boost capability. In addition, the application of ZSI in DC sources is limited due to the discontinuous input current [2]. To overcome these drawbacks, several pulse width modulation (PWM) methods have been proposed to obtain higher boost ability and lower voltage stress on switches, such as maximum boost control [3] and constant maximum boost control [4]. However, the improvement of boost ability is limited, and the discontinuous input current cannot be avoided.

A class of quasi-Z source inverter (qZSI) shown in Fig. 1(a) was first proposed by Peng [5, 6], which has a continuous input current, fewer power devices with lower ratings and common ground between DC source and inverter. However, its practical boost ability is still limited. For this converter, higher voltage gain requires higher shoot-through duty ratio and lower modulation index, which leads to low output power quality and high voltage stress across switches and passive components [1].

To increase the boost capability of qZSI, many attempts have been made in recent years. A class of transformer-based
qZSI, such as trans-qZSI [7] and T-source inverter [8], has been proposed by replacing two separate inductors with magnetically coupled inductors, and the DC-link voltage can be boosted by changing the turns ratio. However, without any snubber circuit, the large switch-voltage spikes are produced by the leakage inductance of the coupled inductor. Improved trans-qZSI, proposed in [9], further upgraded the boost inversion ability and improved the input current profile, like suppression of inrush current at start-up. Nonetheless, more resonances and spikes of DC-link voltage are produced due to the additional inductors and capacitors.

Switched inductor $[10,11]$, switched capacitor $[12,13]$, voltage multiplier $[14,15]$, coupled inductor $[16,17]$ and voltage lift $[18,19]$ techniques are commonly used in transformerless dc-dc converter to obtain high step-up conversion ratio. Some of the techniques have been employed to qZSI [20-24] while maintaining the single-stage inversion. Fig. 1(b) shows a combination of ZSI and switched-inductor (SL) technique (simplified as SL-ZSIs) which has been presented in $[20,21]$, in order to break the boost limitation of the classic ZSI. The switched-inductor quasi-Z source inverter (SL-qZSI) was also proposed in [22], which has a continuous input current and fewer passive components as well as lower voltage stress on them compared to SL-ZSI. An improved SL-qZSI was proposed in [23] by replacing a diode in the switched-inductor with a bootstrap capacitor, which further increased the boost ability, and decreased the voltage stress on components as well as the current ripple in the input inductor. A combination of a three-winding switchedcoupled inductor and switched capacitor technique was employed with the qZSI in the SCL-qZSI, which was proposed in [24]. It obtains the higher boost ability B than that of the existing high voltage gain qZSI and trans-ZSI and suppresses the startup inrush current while retaining all of the advantages of classic qZSI topology. However, the high boost ability of the SCL-qZSI is at the cost of the large count of passive components and smaller operation range, where the shoot-through duty ratio cannot exceed 0.25 .

In this paper, a combination of coupled-inductor technique and qZSI, termed as CI-qZSI, is proposed. Compared with the classic qZSI and the SL-qZSI shown in Fig.1, the proposed inverter achieves a higher boost factor of 2/(1-3D), with reduced sizes and number of passive components. It also has a greater current handling capability with a lower input current ripple and a better suppression of startup inrush current. Furthermore, it also achieves lower 
voltage and current stresses across components for the same input and output voltage. The operation principle and analysis of the proposed topology is presented. Afterward, the topology is theoretically compared with the classic qZSI and SL-qZSI. The possibility of combining the basic structure of the proposed converter with multiple coupled inductor cells is discussed. Finally, the feasibility of the proposed CI-qZSI is validated by simulations.

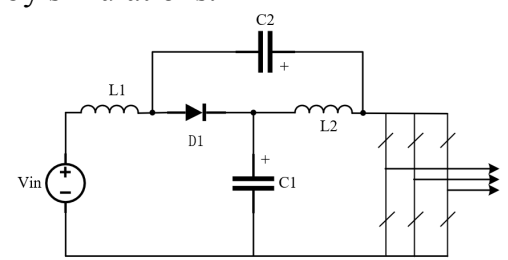

(a) Quasi-Z source inverter (qZSI)

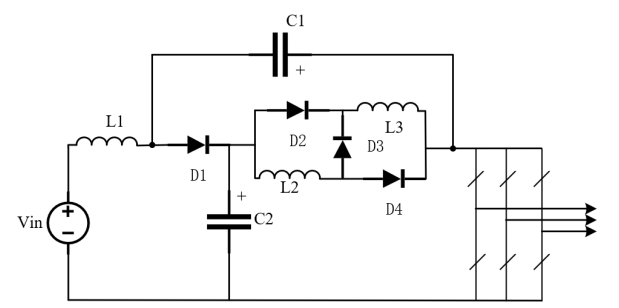

(b) Switched-inductor quasi-Z source inverter (SL-qZSI)

Fig. 1. Classic Quasi-Z source inverter topologies.

\section{PROPOSED CONVERTER}

Fig. 2 shows the circuit of the proposed coupled inductor qZSI (CI- qZSI), which is obtained by the standard qZSI in combination with a coupled inductor based voltage multiplier cell. The proposed inverter consists of two diodes $\left(\mathrm{D}_{1}\right.$ and $\left.\mathrm{D}_{2}\right)$, three capacitors $\left(\mathrm{C}_{1}, \mathrm{C}_{2}\right.$ and $\left.\mathrm{C}_{3}\right)$, an input inductor $\mathrm{L}$ and coupled windings (N1 and N2). The turn ratio of windings $\mathrm{N} 2$ to $\mathrm{N} 1$ is $\mathrm{n}$.

\section{A. Circuit Analysis}

The operation of the proposed topology is similar to that of classic qZSI, which contains a shoot-through state besides six traditional active states and two zero states. For the purpose of analysis, the operating states are simplified to two states: shoot-through state and nonshoot-through state. Fig. 3 shows the equivalent circuit including the magnetizing inductance $\mathrm{L}_{\mathrm{m}}$ and two small leakage inductances $\mathrm{L}_{\mathrm{lk} 1}$ and $\mathrm{L}_{\mathrm{lk} 2}$ of windings N1 and N2.

\section{1) Shoot-Through State}

As shown in Fig. 4 (a), both switches of each phase leg in the inverter bridge turn on simultaneously during the shoot-through state. Diodes $D_{1}$ is off and $D_{2}$ is on. The inductor $\mathrm{L}$ is charged by input $\mathrm{DC}$ voltage source and capacitor $\mathrm{C}_{2}$, while the winding $\mathrm{N} 1$ is charged by capacitor $C_{1}$ through diode $D_{2}$. The capacitor $C_{3}$ is charged by winding N2 passing through diode $\mathrm{D}_{2}$.

\section{2) Nonshoot-Through State}

The nonshoot-through state shown in Fig. 4 (b) consists of traditional six states and two zero states. During this state, the diode $D_{1}$ is on and $D_{2}$ is off. The input inductor $L 1$ is discharged to $C_{1}$ through $D_{1}$, while the capacitor $C_{2}$ is charged by winds $\mathrm{N} 1, \mathrm{~N} 2$ and capacitor $\mathrm{C}_{3}$. In addition, the energy stored in the leakage inductance of $\mathrm{N} 1$ and $\mathrm{N} 2$ is absorbed byC $\mathrm{C}_{2}$, therefore switch-voltage spikes are avoided.

\section{B. Step-up Ability of The Proposed Inverter}

The boost factor $\mathrm{B}$ of the proposed inverter is the voltage gain between the DC-link voltage of the inverter $V_{P N}$ and input dc voltage $V_{i n}$. Similar to the derivation of the boost factor for SCL-qZSI [24] and trans-ZSIs [7], the small leakage inductance is ignored to derive its boost factor. The simplified circuits of the proposed topology during the two states are shown in Fig. 4 (a) and (b), respectively.

During the shoot-through state, the following equations can be derived by applying Kirchhoff's Voltage Law:

$\left\{\begin{array}{l}\mathrm{V}_{\mathrm{L}}=\mathrm{V}_{\mathrm{in}}+\mathrm{V}_{\mathrm{C} 2} \\ \mathrm{~V}_{\mathrm{N} 1}=\mathrm{V}_{\mathrm{C} 1} \\ \mathrm{~V}_{\mathrm{N} 2}=\mathrm{V}_{\mathrm{C} 3}\end{array}\right.$

The voltage of secondary coupled winding N2 is directly proportional to that of primary winding $\mathrm{N} 1$ all the time:

$\mathrm{V}_{\mathrm{N} 2}=\mathrm{nV}_{\mathrm{N} 1}$

where $\mathrm{n}$ is the turn ratio of windings $\mathrm{N} 2$ to N1. Therefore, the capacitor voltage $V_{C 3}$ is equal to $n$ times $V_{C 1}$.

Similarly, the equations in the nonshoot-through state are derived as:

$\left\{\begin{array}{l}\mathrm{V}_{\mathrm{L}}=\mathrm{V}_{\mathrm{PN}}-\mathrm{V}_{\mathrm{in}}-\mathrm{V}_{\mathrm{C} 2} \\ \mathrm{~V}_{\mathrm{N} 1}+\mathrm{V}_{\mathrm{N} 2}=\mathrm{V}_{\mathrm{PN}}-\mathrm{V}_{\mathrm{C} 1}-\mathrm{V}_{\mathrm{C} 3} \\ \mathrm{~V}_{\mathrm{N} 1}+\mathrm{V}_{\mathrm{N} 2}=\mathrm{V}_{\mathrm{C} 2}-\mathrm{V}_{\mathrm{C} 3}\end{array}\right.$

The shoot-through duty cycle is D and DT is the shootthrough time interval, then $(1-\mathrm{D}) \mathrm{T}$ is the nonshoot-through time interval. Applying the voltage-second balance equation on input inductor $\mathrm{L}$, the following equation can be derived according to (1) and (5):

$\mathrm{V}_{\mathrm{PN}}=\frac{1}{1-\mathrm{D}}\left(\mathrm{V}_{\mathrm{in}}+\mathrm{V}_{\mathrm{C} 2}\right)$

Similarly, applying the voltage-second balance condition on winding N1, equation (9) can be derived from (2), (4) and (7): $\mathrm{V}_{\mathrm{C} 1}=\frac{1-\mathrm{D}}{\mathrm{n}+1} \mathrm{~V}_{\mathrm{PN}}$

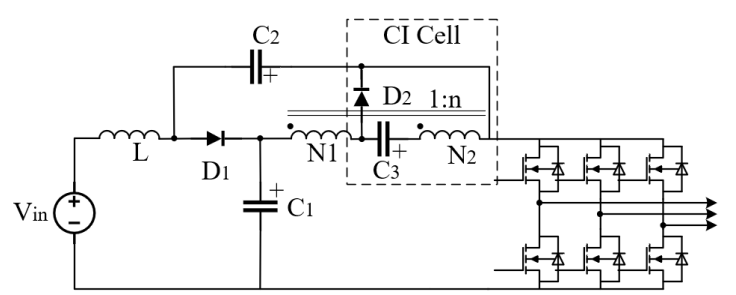

Fig. 2. Proposed qZSI with Coupled Inductor (CI) cell

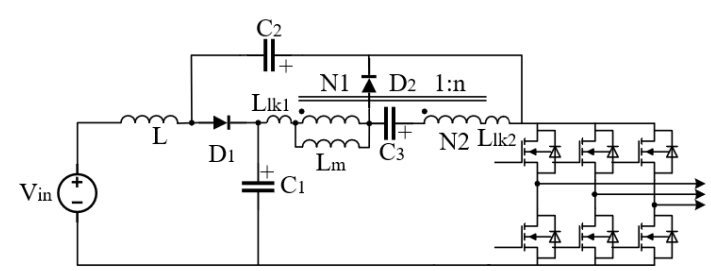

Fig. 3. Equivalent circuit of the proposed inverter.

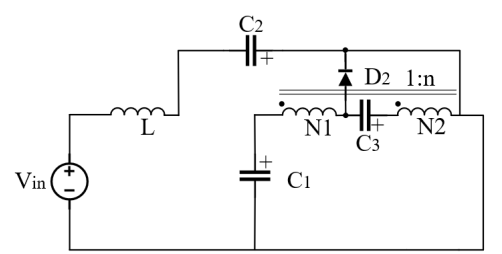

(a) Shoot-through state 


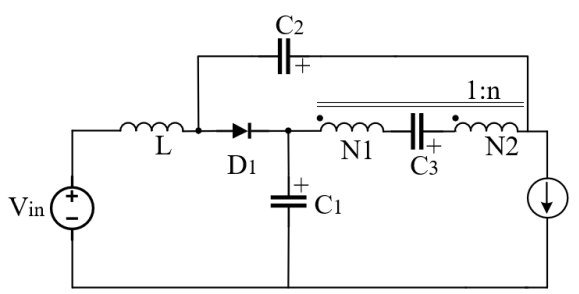

(b) Nonshoot-through state

Fig. 4. Equivalent circuit of the proposed topology.

From (6) and (7), the relation between DC-link voltage and capacitor voltage $\mathrm{V}_{\mathrm{C} 1}$ and $\mathrm{V}_{\mathrm{C} 2}$ can be acquired:

$\mathrm{V}_{\mathrm{PN}}-\mathrm{V}_{\mathrm{C} 1}=\mathrm{V}_{\mathrm{C} 2}$

Substituting (9) into (10), the capacitor voltage $V_{C 2}$ can be expressed as:

$\mathrm{V}_{\mathrm{C} 2}=\frac{\mathrm{n}+\mathrm{D}}{\mathrm{n}+1} \mathrm{~V}_{\mathrm{PN}}$

From (8) and (11), the DC-link voltage $\mathrm{V}_{\mathrm{PN}}$ across the inverter bridge is:

$\mathrm{V}_{\mathrm{PN}}=\frac{\mathrm{n}+1}{1-(\mathrm{n}+2) \mathrm{D}} \mathrm{V}_{\mathrm{in}}$

Thus, the boost factor B of the proposed inverter can be expressed as:

$\mathrm{B}=\frac{\mathrm{n}+1}{1-(\mathrm{n}+2) \mathrm{D}}, \mathrm{D}<\frac{1}{\mathrm{n}+2}$

\section{Generalization of the Basic Proposed Structure}

To further increase the boost ability of the proposed structure, multiple secondary windings coupled-inductor cells are added to the classic qZSI as shown in Fig. 5. The relation between DC-link voltage $\mathrm{V}_{\mathrm{PN}}$ and input DC source voltage $\mathrm{V}_{\text {in }}$ can be derived as:

$\mathrm{V}_{\mathrm{PN}}=\frac{\mathrm{n} * \mathrm{~N}_{\mathrm{CI}}+1}{1-\left(\mathrm{n}+\mathrm{N}_{\mathrm{CI}}+2\right) \mathrm{D}} \mathrm{V}_{\mathrm{in}}$

Where $\mathrm{n}$ is the turn ratio and $\mathrm{N}_{\mathrm{CI}}$ is the number of coupled inductor cells. Therefore, the boost factor $\mathrm{B}$ is:

$B=\frac{n * N_{C I}+1}{1-\left(n+N_{C I}+2\right) D}, D<\frac{1}{n+N_{C I}+2}$

It can be seen that the range of shoot-through duty ratio $\mathrm{D}$ is further decreased with the increasing number of coupledinductor cells $\mathrm{N}_{\mathrm{CI}}$ and turns ratio $\mathrm{n}$. To sum up, the generalized structure of the proposed structure can achieve a higher boost ability at the cost of limited operation range and a large number of passive components.

\section{COMPARISON WITH PREVIOUS TOPOLOGIES}

In this section, qZSI [6] and SL-qZSI [22] are selected to compare with the proposed inverter from several aspects, such as voltage gain, voltage stress and current stress on active switches and passive components and input current ripple.

\section{A. Voltage Gain}

When the turns ratio $\mathrm{n}$ is equal to 1 , the boost factor is $2 /(1-3 \mathrm{D})$ and the range of duty ratio cannot exceed $1 / 3$ in order to yield high boost ability. Fig. 6 indicates the boost factor versus the duty ratio for three qZSI-based topologies in simple boost control method. The proposed inverter has a higher step-up ability than that of classic qZSI [6] and SLqZSI [22].

According to simple boost control in [1], the relation between shoot-through duty ratio $\mathrm{D}$ and modulation index $\mathrm{M}$ is:

$\mathrm{D}=\frac{\mathrm{T}_{0}}{\mathrm{~T}}=1-\mathrm{M}$
The boost factor $\mathrm{B}$ can be expressed by modulation index $\mathrm{M}$ as:

$\mathrm{B}=\frac{2}{3 \mathrm{M}-2}$

The peak phase-to-phase voltage $\widehat{\mathrm{V}_{\mathrm{ph}}}$ of the inverter is:

$\widehat{V_{\mathrm{ph}}}=\frac{\mathrm{MV}_{\mathrm{PN}}}{2}=\frac{\mathrm{MBV}_{\mathrm{in}}}{2}$

Substituting (16) into (17), the voltage gain G (MB) can be derived as:

$\mathrm{G}=\frac{\widehat{\mathrm{V}_{\mathrm{ph}}}}{\left(\frac{\mathrm{V}_{\text {in }}}{2}\right)}=\frac{2 \mathrm{M}}{3 \mathrm{M}-2}$

The voltage gain $G$ versus the modulation index $M$ for qZSI-based topologies is shown in Fig. 7. It can be seen that the higher modulation index $\mathrm{M}$ is required by the proposed topology for the same voltage gain $\mathrm{G}$ due to its high step-up ability. Therefore, compared to the other topologies, the proposed inverter can achieve better output performance by applying a high modulation index when it requires the same voltage conversion ratio.

\section{B. Voltage Stress On Switches}

The voltage stress across the switches of inverter bridges $\mathrm{V}_{\mathrm{SW}}$ is equal to the DC-link voltage $\mathrm{V}_{\mathrm{PN}}$, which is in relation with boost factor $\mathrm{B}$, accordingly with modulation index $\mathrm{M}$ and voltage gain $\mathrm{G}$. Based on the derivation above, the voltage stress on switches can be expressed as:

$\mathrm{V}_{\mathrm{SW}}=\mathrm{BV}_{\text {in }}=\left(\frac{3 \mathrm{G}-2}{2}\right) \mathrm{V}_{\text {in }}$

Fig. 8 shows the Normalized voltage stress/ Input voltage versus the voltage gain $G$ for three qZSI-based topologies. It can be observed that the proposed topology requires the lowest voltage stress on switches for the same voltage gain $\mathrm{G}$ due to its highest step-up ratio.

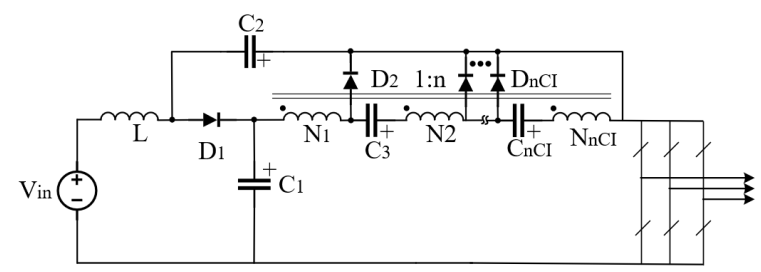

Fig. 5. Proposed inverter with multiple secondary windings coupledinductor cells.

\section{Voltage Current Stresses On Passive Components}

If the duty ratio $D$ and the input voltage $V_{\text {in }}$ are fixed, the summary of stresses on components of three different topologies are presented in Table I. In this case, it can be observed that the passive components in the proposed inverter suffer higher voltage current stress than those of the other topologies. It is because of the higher boost ability of the proposed inverter. Specifically, $S_{d}$ represents the shootthrough state with the value of 1 , whereas $\overline{S_{d}}$ is equal to 1 during the nonshoot-through state.

At the same input voltage $V_{\text {in }}$ and the same output phase voltage $V_{p h}$ with fixed voltage gain $G$, the voltage and current stresses comparison of three topologies are shown in Table II. In this case, lower voltage and current stress on components are achieved by the proposed inverter due to its strong boost ability. 


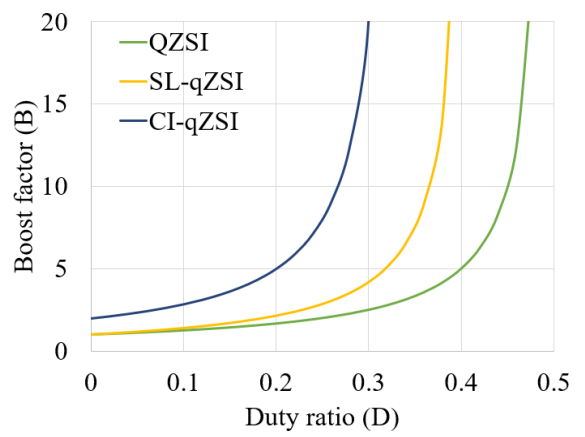

Fig. 6. The boost factor (B) versus the duty ratio (D).

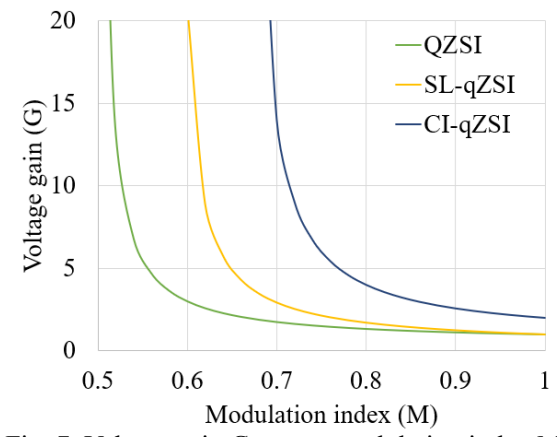

Fig. 7. Voltage gain $\mathrm{G}$ versus modulation index $\mathrm{M}$

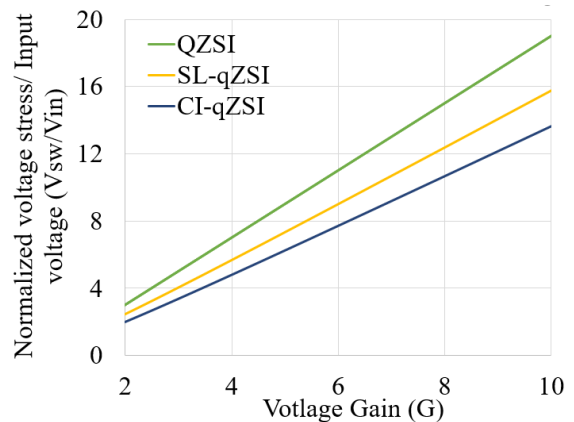

Fig. 8. Normalized voltage stress/ Input voltage versus the voltage gain G.

\section{Input Current Ripple}

Due to the common ground designs of three qZSI-based topologies, all of them have continuous input current. In order to compare the input current ripple in those topologies, the following equations are derived by [24]:

$\Delta \mathrm{i}_{\mathrm{L} 1}=\frac{\mathrm{V}_{\mathrm{L} 1}}{\mathrm{~L}} \mathrm{DT}$

Where $\mathrm{L}$ is the value of inductance, $\mathrm{T}$ is the shootthrough period, $\Delta \mathrm{i}_{\mathrm{L} 1}$ is the input current ripple, $\mathrm{V}_{\mathrm{L}}$ is the voltage on the input inductor $\mathrm{L}$ during the shoot-through state. For the same input voltage Vin and fixed voltage gain $\mathrm{G}$, the relation between the value of inductance $\mathrm{L}_{1}$ and input current ripple $\Delta \mathrm{i}_{\mathrm{L} 1}$ can be derived by replacing duty ratio $\mathrm{D}$ with voltage gain $\mathrm{G}$ in Table II:

$\Delta \mathrm{i}_{\mathrm{L} 1}=\frac{\mathrm{V}_{\mathrm{L} 1} \mathrm{~T}(\mathrm{G}-2)}{\mathrm{L}_{1}(3 \mathrm{G}-2)}$

Fig. 9 shows the normalized input current ripples versus inductance in the same input voltage $V_{\text {in }}$ and voltage gain $G$. It is obvious that the lower input current ripple across the input inductor by the same inductance in the proposed inverter. Alternatively, for the same current ripple, the prosed topology requires the lower value and smaller size of the input inductor.

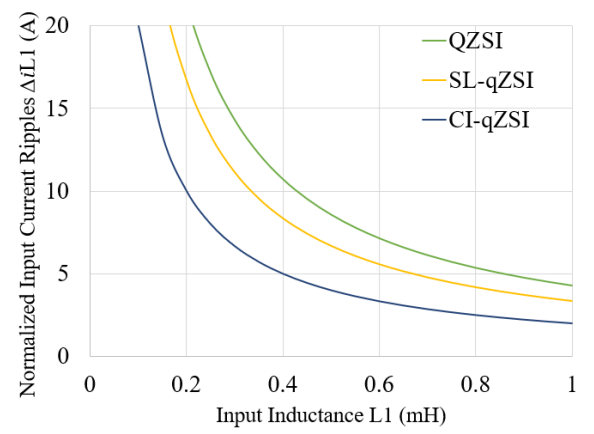

Fig. 9. Normalized input current ripples versus inductance in the same input voltage $V_{\text {in }}$ and voltage gain $G$.

Table I. Summary of stresses with the same input voltage and duty ratio.

\begin{tabular}{|c|c|c|c|}
\hline & qZSI [6] & SL- qZSI [22] & $\mathrm{Cl}-\mathrm{qZSI}(\mathrm{n}=1)$ \\
\hline $\mathrm{V}_{\mathrm{PN}}$ & $\frac{1}{1-2 D} V_{\text {in }}$ & $\frac{1+D}{1-2 D-D^{2}} V_{\text {in }}$ & $\frac{2}{1-3 D} V_{\text {in }}$ \\
\hline $\mathrm{V}_{\mathrm{C}}$ & $\begin{array}{l}V_{C 1}=\frac{1-D}{1-2 D} V_{\text {in }} \\
V_{C 2}=\frac{D}{1-2 D} V_{\text {in }}\end{array}$ & $\begin{array}{l}\mathrm{V}_{\mathrm{C} 1}=\frac{1-\mathrm{D}}{1-2 \mathrm{D}-\mathrm{D}^{2}} \mathrm{~V}_{\mathrm{in}} \\
\mathrm{V}_{\mathrm{C} 2}=\frac{2 \mathrm{D}}{1-2 \mathrm{D}-\mathrm{D}^{2}} \mathrm{~V}_{\mathrm{in}}\end{array}$ & $\begin{array}{c}\mathrm{V}_{\mathrm{C} 1}=\frac{1-\mathrm{D}}{1-3 \mathrm{D}} \mathrm{V}_{\mathrm{in}} \\
\mathrm{V}_{\mathrm{C} 2}=\frac{1+\mathrm{D}}{1-3 \mathrm{D}} \mathrm{V}_{\mathrm{in}} \\
\mathrm{V}_{\mathrm{C} 3}=\mathrm{V}_{\mathrm{C} 1}\end{array}$ \\
\hline $\mathrm{V}_{\mathrm{D}}$ & $V_{D}=V_{P N}$ & $\begin{array}{c}\mathrm{V}_{\mathrm{D} 1}=\mathrm{V}_{\mathrm{PN}}, \mathrm{V}_{\mathrm{D} 2}=\mathrm{V}_{\mathrm{C} 1} \\
\mathrm{~V}_{\mathrm{D} 3,4}=\frac{\mathrm{D}}{1-\mathrm{D}} \mathrm{V}_{\mathrm{C} 1}\end{array}$ & $\begin{array}{l}V_{D 1}=V_{P N} \\
V_{D 2}=\frac{V_{P N}}{2}\end{array}$ \\
\hline$\widehat{\mathrm{V}_{\mathrm{ph}}}$ & $(1-D) \frac{V_{P N}}{2}$ & $(1-D) \frac{V_{P N}}{2}$ & $(1-D) \frac{V_{P N}}{2}$ \\
\hline $\mathrm{I}_{\mathrm{D} 1}$ & $\frac{I_{\text {in }}}{1-D}$ & $\frac{\mathrm{I}_{\text {in }}}{1-\mathrm{D}}$ & $\frac{\mathrm{I}_{\text {in }}}{1-\mathrm{D}}$ \\
\hline $\mathrm{I}_{\mathrm{sh}}$ & $2 \mathrm{I}_{\text {in }}$ & $\frac{3+D}{1+D} I_{\text {in }}$ & $\frac{1+3 \mathrm{D}}{2 \mathrm{D}} \mathrm{I}_{\mathrm{in}}$ \\
\hline $\mathrm{I}_{\mathrm{L}}$ & $\mathrm{I}_{\mathrm{L} 1,2}=\mathrm{I}_{\mathrm{in}}$ & $\begin{array}{c}\mathrm{I}_{\mathrm{L} 1}=\mathrm{I}_{\mathrm{in}} \\
\mathrm{I}_{\mathrm{L} 2}=\frac{\mathrm{I}_{\text {in }}}{1+\mathrm{D}}\end{array}$ & $\begin{array}{c}\mathrm{I}_{\mathrm{L} 1}=\mathrm{I}_{\mathrm{in}}, \mathrm{I}_{\mathrm{m}}=\mathrm{I}_{\mathrm{in}} \\
\mathrm{I}_{\mathrm{N} 1}=\mathrm{S}_{\mathrm{d}} \cdot\left(\frac{1+\mathrm{D}}{2 \mathrm{D}}\right) \mathrm{I}_{\mathrm{in}} \\
\mathrm{I}_{\mathrm{N} 2}=\mathrm{S}_{\mathrm{d}} \cdot\left(\mathrm{I}_{\mathrm{N} 1}-\mathrm{I}_{\mathrm{in}}\right) \\
\mathrm{I}_{\mathrm{N} 1,2}=\overline{\mathrm{S}_{\mathrm{d}}} \cdot\left(\mathrm{I}_{\mathrm{m}} / 2\right)\end{array}$ \\
\hline
\end{tabular}

Table II Summary of stresses with the same input voltage $V_{\text {in }}$ and output phase voltage $\mathrm{V}_{p h}$.

\begin{tabular}{|c|c|c|c|}
\hline & qZSI [6] & SL- qZSI [22] & $\mathrm{Cl}-\mathrm{qZSI}(\mathrm{n}=1)$ \\
\hline $\mathrm{D}$ & $\mathrm{G}-1$ & $G-\sqrt{2 G^{2}-2 G+1}$ & $\mathrm{G}-2$ \\
\hline & $\overline{2 \mathrm{G}-1}$ & $1-\mathrm{G}$ & $\overline{3 G-2}$ \\
\hline $\mathrm{V}_{\mathrm{PN}}$ & $(2 G-1) V_{\text {in }}$ & $\frac{(1-G)\left(1-\sqrt{2 G^{2}-2 G+1}\right)}{-2 G+2 \sqrt{2 G^{2}-2 G+1}} V_{\text {in }}$ & $\frac{3 \mathrm{G}-2}{2} \mathrm{~V}_{\mathrm{in}}$ \\
\hline $\mathrm{V}_{\mathrm{C}}$ & $\mathrm{V}_{\mathrm{C} 1}=\mathrm{GV}_{\mathrm{in}}, \mathrm{V}_{\mathrm{C} 2}=(\mathrm{G}-1) \mathrm{V}_{\mathrm{in}}$ & $V_{C 1}=\frac{(1-G)\left(1-2 G+\sqrt{2 G^{2}-2 G+1}\right)}{-2 G+2 \sqrt{2 G^{2}-2 G+1}} V_{i n}, V_{C 2}=(G-1) V_{i n}$ & $V_{C 1}=\frac{G}{2} V_{i n}, V_{C 2}=(G-1) V_{i n}, V_{C 3}=V_{C 1}$ \\
\hline$\widehat{\mathrm{V}_{\mathrm{ph}}}$ & $\mathrm{GV}_{\mathrm{in}} / 2$ & $\mathrm{GV}_{\mathrm{in}} / 2$ & $\mathrm{GV}_{\mathrm{in}} / 2$ \\
\hline $\mathrm{I}_{\mathrm{D} 1}$ & $\frac{(2 \mathrm{G}-1)}{\mathrm{G}} \mathrm{I}_{\mathrm{in}}$ & $\frac{1-G}{1-G+\sqrt{2 G^{2}-2 G+1}} I_{\text {in }}$ & $\frac{3 \mathrm{G}-2}{2 \mathrm{G}} \mathrm{I}_{\mathrm{in}}$ \\
\hline $\mathrm{I}_{\mathrm{sh}}$ & $2 \mathrm{I}_{\text {in }}$ & $\frac{3-2 \mathrm{G}-\sqrt{2 \mathrm{G}^{2}-2 \mathrm{G}+1}}{1-\sqrt{2 \mathrm{G}^{2}-2 \mathrm{G}+1}} \mathrm{I}_{\mathrm{in}}$ & $\frac{3 \mathrm{G}-4}{\mathrm{G}-1} \mathrm{I}_{\mathrm{in}}$ \\
\hline $\mathrm{I}_{\mathrm{L}}$ & $\mathrm{I}_{\mathrm{L} 1,2}=\mathrm{I}_{\mathrm{in}}$ & $\mathrm{I}_{\mathrm{L} 2}=\frac{\mathrm{I}_{\mathrm{L} 1}=\mathrm{I}_{\text {in }}}{1-\sqrt{2 \mathrm{G}^{2}-2 \mathrm{G}+1}}$ & $\begin{array}{c}\mathrm{I}_{\mathrm{L} 1}=\mathrm{I}_{\mathrm{in}}, \mathrm{I}_{\mathrm{m}}=\mathrm{I}_{\mathrm{in}} \\
\mathrm{I}_{\mathrm{N} 1}=\mathrm{S}_{\mathrm{d}} \cdot\left(\frac{2 \mathrm{G}-2}{\mathrm{G}-2}\right) \mathrm{I}_{\mathrm{in}} \\
\mathrm{I}_{\mathrm{N} 2}=\mathrm{S}_{\mathrm{d}} \cdot\left(\mathrm{I}_{\mathrm{N} 1}-\mathrm{I}_{\mathrm{in}}\right), \mathrm{I}_{\mathrm{N} 1,2}=\overline{\mathrm{S}_{\mathrm{d}}} \cdot\left(\mathrm{I}_{\mathrm{m}} / 2\right)\end{array}$ \\
\hline
\end{tabular}




\section{Simulation Results}

To verify the theoretical analysis, the simulation of the proposed inverter is employed in Simulink/ Matlab. Table III presents the specifications of the proposed topology. The input dc voltage is selected as $150 \mathrm{~V}$ and the output phase-tophase voltage is $240 \mathrm{~V}_{\mathrm{RMS}}$ to meet the grid-tied requirement. The values of passive components are selected as $\mathrm{L}=700 \mu \mathrm{H}$, $\mathrm{C}_{1}=\mathrm{C}_{2}=\mathrm{C}_{3}=200 \mu \mathrm{F}$, and the magnetizing inductance is $100 \mu \mathrm{H}$ and leakage inductance is $0.2 \mu \mathrm{H}$. The output filter inductors and capacitors are $1 \mathrm{mH}$ and $20 \mu \mathrm{F}$ and a three-phase resistive load of $30 \Omega$ /phase is selected. Specifically, the simple boost control method is employed in all of the qZSI-based topologies. Voltage gain $\mathrm{G}$ of 4.52 is needed in simple boost control, therefore the values of parameters are theoretically calculated from Table III, $\mathrm{D}=0.22, \mathrm{~B}=5.78, \mathrm{~V}_{\mathrm{PN}}=867 \mathrm{~V}$, $\mathrm{V}_{\mathrm{C} 1}=339 \mathrm{~V}, \mathrm{~V}_{\mathrm{C} 2}=528 \mathrm{~V}$, and $\mathrm{V}_{\mathrm{C} 3}=339 \mathrm{~V}$.

Table III Specifications of the proposed inverter.

\begin{tabular}{|l|l|}
\hline Input voltage & $150 \mathrm{Vdc}$ \\
\hline Output phase voltage & $240 \mathrm{~V}_{\mathrm{RMS}}$ \\
\hline Z-source capacitor $\left(\mathrm{C}_{1}, \mathrm{C}_{2}, \mathrm{C}_{3}\right)$ & $200 \mu \mathrm{F}$ \\
\hline Z-source inductor $(\mathrm{L})$ & $700 \mu \mathrm{H}$ \\
\hline Coupled inductor $\left(\mathrm{L}_{\mathrm{N} 1}, \mathrm{~L}_{\mathrm{N} 2}, \mathrm{n}=1\right)$ & $\mathrm{L}_{\mathrm{m}}=100 \mu \mathrm{H}, \mathrm{L}_{\mathrm{lk}}=0.2 \mu \mathrm{H}$ \\
\hline Output filter inductor $\left(\mathrm{L}_{\mathrm{f}}\right)$ & $1 \mathrm{mH}$ \\
\hline Output filter capacitor $\left(\mathrm{C}_{\mathrm{f}}\right)$ & $20 \mu \mathrm{F}$ \\
\hline Switching frequency $(\mathrm{f})$ & $10 \mathrm{kHz}$ \\
\hline Three-phase resistive load $\left(\mathrm{R}_{\mathrm{l}}\right)$ & $30 \Omega /$ phase \\
\hline
\end{tabular}

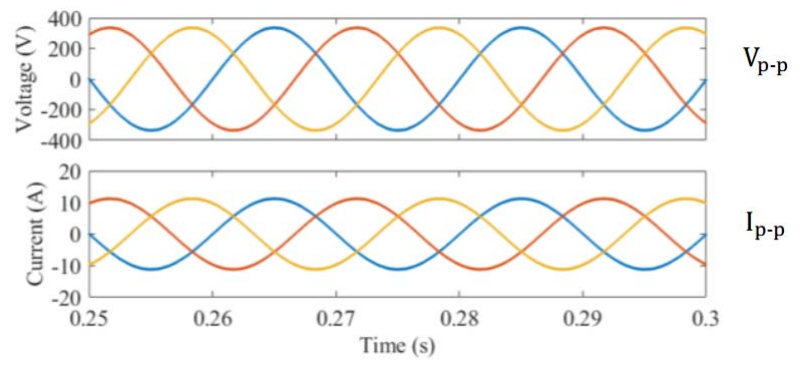

(a)
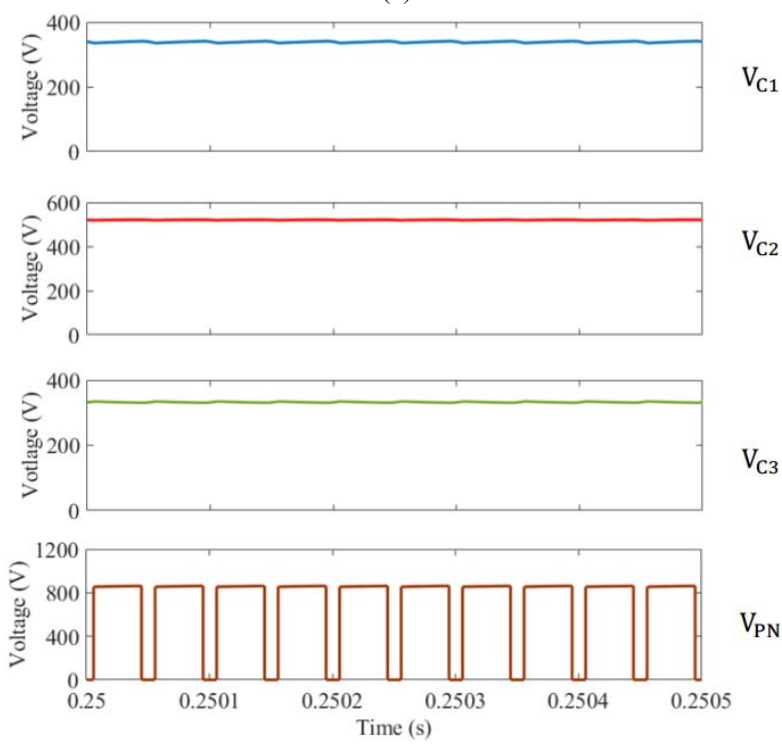

(b)

Fig. 10. Simulation results of the proposed inverter. (a) Three-phase output phase-to-phase voltage and current. (b) Capacitor voltage and dc-link voltage.
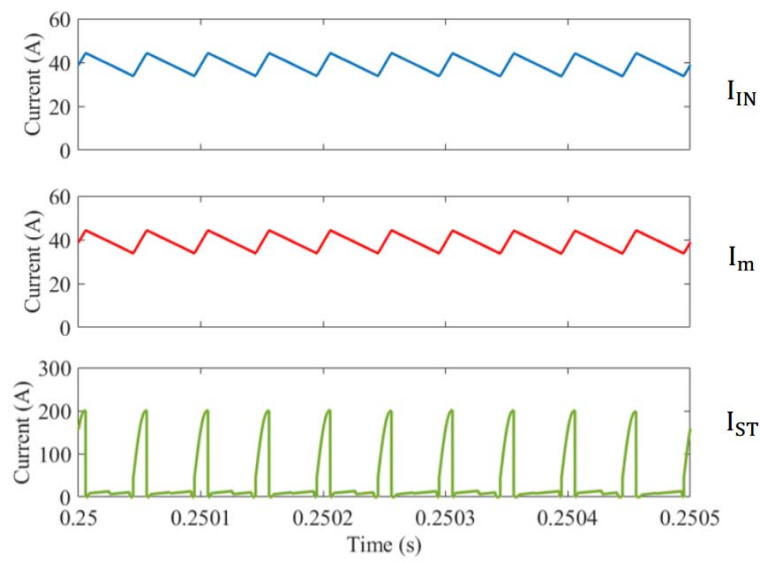

(a)
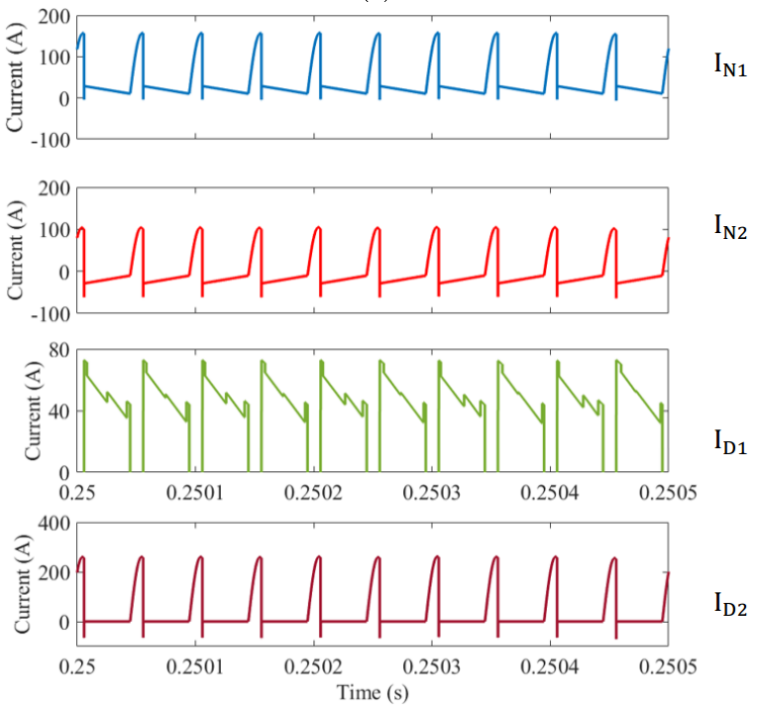

(b)

Fig. 11. Current stress across components in the proposed inverter. (a) Input inductor current, magnetizing current, and shoot-through current. (b) Winding currents and diode currents.

Fig. 10 present the simulation results of the proposed inverter. It can be seen that capacitor voltage $\mathrm{C}_{1}, \mathrm{C}_{2}, \mathrm{C}_{3}$ are $338 \mathrm{~V}, 520 \mathrm{~V}, 332 \mathrm{~V}$ and DC-link voltage $\mathrm{V}_{\mathrm{PN}}$ is $860 \mathrm{~V}$, which match the theoretical results. The current across components is shown in Fig. 11.

When the simple boost control is applied to produce the same input $(200 \mathrm{~V})$ and output voltage $\left(240 \mathrm{~V}_{\mathrm{RMS}}\right)$, the comparison of voltage stress on inverter switches in three qZSI-based inverters is shown in Fig. 12. In this case, the modulation index $\mathrm{M}$ of the classic qZSI, SL-qZSI, and the proposed CI-qZSI are $0.6,0.69$ and 0.83 respectively. It can be observed that lower voltage stress across switches in the proposed inverter $(796 \mathrm{~V})$ compared to those in the qZSI $(1062 \mathrm{~V})$ and the SL-qZSI (889V). Furthermore, the spike voltage in the proposed inverter $(1192 \mathrm{~V})$ is also much lower than those in the other qZSI-based topologies (qZSI with $2027 \mathrm{~V}$ and SL-qZSI with 1613V).

Fig. 13 indicates the input current across the input inductor. The proposed inverter obtains the lowest input inrush current of $231 \mathrm{~A}$ and the smallest input current ripple of $8.3 \mathrm{~A}$, while the input inrush current of $542 \mathrm{~A}$ and input current ripple of $18.5 \mathrm{~A}$ in the qZSI and the input inrush current of 418A and input current ripple of 13.0A in the SLqZSI. In conclusion, the proposed inverter has better current handling capability and lower voltage stress on switches due to its higher boost ability. 


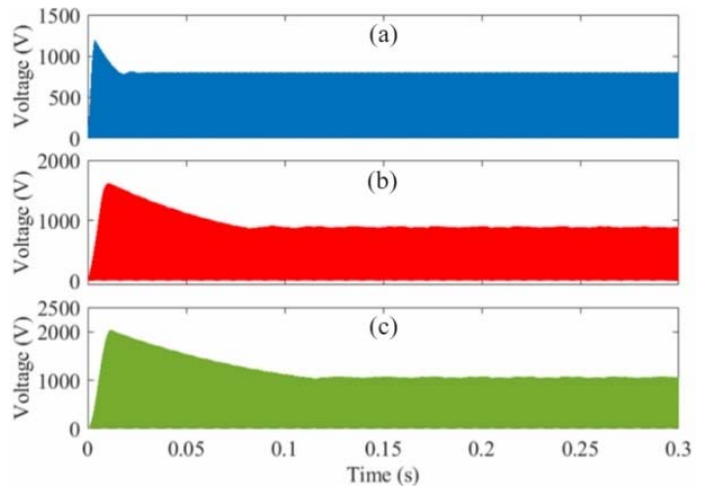

Fig. 12 Simulation results of DC-link voltage in (a) CI-qZSI. (b) SL-qZSI and (c) qZSI.

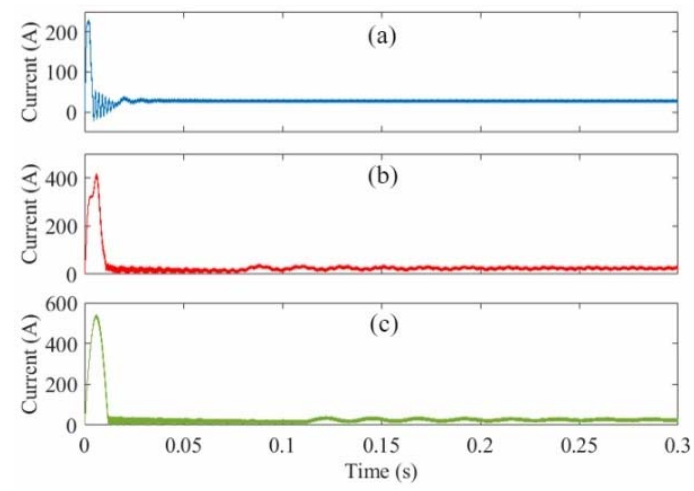

Fig. 13 Simulation results of input current in (a) CI-qZSI. (b) SL-qZSI and (c) qZSI.

\section{CONCLUSIONS}

This paper proposed a CI-qZSI with the following characteristics: high boost voltage ability, common ground between DC source and inverter and continuous input current. For the same input and output voltage, the proposed CI-qZSI provides the lower voltage stress on capacitors and active switches, reduced current stress on the inductor. Furthermore, it offers better current handle capability, such as suppression of inrush input current and reduced current ripple.

The simulation results have been verified the proposed inverter has higher boost inversion ability and reduced voltage stress across switches compared to the classic qZSI [6] and SL-qZSI [22] for dc $200 \mathrm{~V}$ and ac $240 \mathrm{~V}_{\text {rms }}$ phase-tophase output.

\section{REFERENCES}

[1] F. Z. Peng, “Z-source inverter," IEEE Trans. Ind. Appl., Vol. 39, No.2, pp. 504-510, Mar./Apr. 2003.

[2] M. S. Shen, A. Joseph, J. Wang, F. Z. Peng, and D. J. Adams, "Comparison of traditional inverters and $\mathrm{z}$-source inverter for fuel cell vehicles," IEEE Trans. Power Electron., Vol.22, No.4, pp.1453- 1463, Jul. 2007.

[3] F. Z. Peng, M. S. Shen, and Z. M. Qian, "Maximum boost control of the Z-source inverter," IEEE Trans. Power Electron., Vol. 20, No .4, pp.833-838, Jul. 2005.
[4] M. S. Shen, J. Wang, A. Joseph, F. Z. Peng, L. M. Tolbert, and D. J. Adams, "Constant boost control of the Z-source inverter to minimize current ripple and voltage stress," IEEE Trans. Ind. Appl., Vol. 42, No. 3, pp.770-778, May/Jun. 2006

[5] J. Anderson and F. Z. Peng, "Four quasi-Z-Source inverters," in Proc, IEEE PESC'08, pp.2743-2749, Jun. 2008.

[6] J. Anderson, and F.Z. Peng, "A Class of Quasi-Z-Source Inverters," in Proc, IEEE IAS '08. Vol. 1, No. 7, pp.5-9, Oct. 2008.

[7] Q. Wei, F. Z. Peng, and H. Cha. "Trans-Z-source inverters." IEEE transactions on power electronics Vol. 26, No.12, pp.3453-3463, 2011.

[8] S. Yang, F. Z. Peng, Q. Lei, R. Inoshita, and Z. Qian, "Current-fed quasi-Z-source inverter with voltage buck-boost and regeneration capability," IEEE Trans. Ind. Appl., Vol. 47, No. 2, pp. 882-892, Mar./Apr. 2011.

[9] N. Minh-Khai, Y. Lim, and S. Park. "Improved trans-Z-source inverter with continuous input current and boost inversion capability." IEEE transactions on power electronics, Vol. 28, No.10, pp.4500-4510, 2013.

[10] B. Axelord, Y. Berkovich, and A. Ioinovici, "Switched capacitor/switched-inductor structures for getting transformerless hybrid dc-dc PWM converters," IEEE Trans. Circuits Syst. I, Fundam. Theory Appl., Vol. 55, No. 2, pp. 687-696, Mar. 2008.

[11] L.-S. Yang, T.-J. Liang, and J.-F. Chen, "Transformerless dc-dc converters with high step-up voltage gain," IEEE Trans. Ind. Electron., Vol. 56, no. 8, pp. 3144-3152, Aug. 2009.

[12] A. Ioinovici, "Switched-capacitor power electronics circuits," IEEE Circuits Syst. Mag., Vol. 1, No. 4, pp. 37-42, Sep. 2001.

[13] H. S.-H. Chung, A. Ioinovici, and W.-L. Cheung, "Generalized structure of bi-directional switched-capacitor dc/dc converters," IEEE Trans. Circuits Syst. I, Fundam. Theory Appl., Vol. 50, No. 6, pp. 743753, Jun. 2003.

[14] S. Iqbal, "A hybrid symmetrical voltage multiplier," IEEE Power Electron. Lett., Vol. 29, No. 1, pp. 6-12, Jan. 2014.

[15] C.-M. Young, M.-H. Chen, T.-A. Chang, C.-C. Ko, and K.-K. Jen, "Cascade Cockcroft-Walton voltage multiplier applied to transformer less high step-up dc-dc converter," IEEE Trans. Ind. Electron., Vol. 60, No. 2, pp. 523-537, Feb. 2013.

[16] X. Hu and C. Gong, "A high voltage gain dc-dc converter integrating coupled-inductor and diode-capacitor techniques," IEEE Trans. Power Electron., Vol. 29, No. 2, pp. 789-800, Feb. 2014.

[17] Y.-P. Hsieh, J.-F. Chen, L.-S. Yang, C.-Y. Wu, and W.-S. Liu, "High conversion-ratio bidirectional dc-de converter with coupled inductor," IEEE Trans. Ind. Electron., Vol. 61, No. 1, pp. 210-222, Jan. 2014.

[18] M. Zhu and F. L. Luo, "Series SEPIC implementing voltage lift technique for dc-dc power conversion," IET Power Electron., Vol. 1, No. 1, pp. 109-121, Mar. 2008.

[19] M. Zhu and F. L. Luo, "Voltage-lift-type Cuk converters: Topology and analysis," IET Power Electron., Vol. 2, No. 2, pp. 178-191, Mar. 2009.

[20] M. Zhu, K. Yu, and F. L. Luo, "Switched inductor Z-source inverter," IEEE Trans. Power Electron., Vol. 25, No. 8, pp. 2150-2158, Aug. 2010.

[21] M. K. Nguyen, Y. C. Lim, Y. H. Chang, and C. J. Moon, "Embedded switched-inductor Z-source inverters," Journal of Power Electronics, Vol. 13, No. 1, pp. 9-19, Jan. 2013.

[22] M. K. Nguyen, Y. C. Lim, and G. B. Cho, "Switched-inductor quasiZ-source inverter," IEEE Trans. Power Electron., Vol. 26, No. 11, pp. 3183-3191, Nov. 2011.

[23] D. Kai, J. Zheng, and J. Mei. "Novel switched-inductor quasi-Z-source inverter." Journal of power Electronics, Vol.14, No.1, pp. 11-21, 2014.

[24] H. F. Ahmed, H. Cha, S. H. Kim, et al. "Switched-coupled-inductor quasi-Z-source inverter." IEEE Transactions on Power Electronics, Vol. 31, No. 2, pp. 1241-1254, 2016. 